\title{
Homeobox Protein CDX-4
}

National Cancer Institute

\section{Source}

National Cancer Institute. Homeobox Protein CDX-4. NCI Thesaurus. Code C126763.

Homeobox protein CDX-4 (284 aa, $\sim 30 \mathrm{kDa}$ ) is encoded by the human CDX4 gene. This protein plays a role in the regulation of embryonic development. 